\title{
Pengelolaan Kesenian Dayakan Desa Kebondalem Bejen Temanggung Sebagai Bagian Dari Upaya Revitalisasi Kesenian Tradisional
}

\author{
Laura Andri Retno M \\ Prodi Sastra Indonesia Fakultas Ilmu Budaya Universitas Diponegoro Semarang \\ lauraandrirm@yahoo.co.id
}

\begin{abstract}
Traditional art is used to express a sense of beauty from within the human soul. As part of culture, traditional art has messages in the form of knowledge, ideas, beliefs and norm values. One example of traditional art is Dayakan. Dayakan is a dance-shaped art owned by the people of Kebondalem Village, Bejen District, Temanggung Regency, Central Java. Through a qualitative descriptive approach with observation and literature techniques, it was found that in order to overcome the expansion of global art and culture, efforts were needed to manage Dayakan arts in order to improve and preserve regional art and culture in the midst of changing times and increasingly intense foreign cultural influences in Indonesia.
\end{abstract}

Keywords: traditional arts, dance, performance, management, cultural preservation.

\begin{abstract}
Abstrak
Kesenian tradisional digunakan untuk mengekspresikan rasa keindahan dari dalam jiwa manusia. Sebagai bagian dari kebudayaan, seni tradisional memiliki pesan berupa pengetahuan, gagasan, kepercayaan dan nilai norma. Salah satu contoh kesenian tradisional adalah Dayakan. Dayakan merupakan kesenian berbentuk tarian yang dimiliki masyarakat Desa Kebondalem Kecamatan Bejen Kabupaten Temanggung Jawa Tengah. Melalui pendekatan deskritif kualitatif dengan teknik observasi dan kepustakaan, ditemukan bahwa untuk mengatasi ekspansi seni dan budaya global diperlukan upaya pengelolaan kesenian Dayakan guna meningkatkan serta melestarikan seni dan budaya daerah di tengah-tengah perubahan zaman dan pengaruh budaya asing yang semakin gencar di Indonesia.
\end{abstract}

Kata kunci: kesenian tradisional, tarian, temanggung, pengelolaan, pelestarian budaya.

\section{PENDAHULUAN}

Masyarakat luas memahami kebudayaan sebagai suatu hal yang mencakup pengetahuan, kepercayaan, kesenian, adat istiadat, serta kebiasaan yang diperoleh dari hasil interaksi dengan orang lain. Kebudayaan diartikan juga sebagai peninggalan sejarah bersifat tradisional seperti tarian daerah, musik daerah, senjata tradisional, bahasa daerah, dan lain sebagainya. Kesenian tradisional sebagai bagian dari budaya tradisional merupakan 
sarana yang dipakai untuk mengekspresikan rasa keindahan dari dalam jiwa manusia. Kesenian ini menyiratkan pesan dari masyarakatnya berupa pengetahuan, gagasan, kepercayaan, nilai serta norma. Ciri khas yang dimiliki kesenian tradisional adalah berkembang secara turun temurun, mempunyai unsur-unsur kepercayaan serta interpretasi tradisi dari masyarakatnya. Kesenian yang tinggal atau terdapat di suatu daerah, maka ia menjadi milik dari daerah tersebut (Sedyawati, 1981: 15).

Budaya dan kesenian Indonesia banyak berkembang di lingkungan tingkat desa. Salah satunya Desa Kebondalem Kecamatan Bejen Kabupaten Temanggung, Jawa Tengah. Kentalnya unsur budaya di desa ini dapat dilihat pada asal usul nama Desa Kebondalem. Informasi dari juru kunci desa, Bapak Sukirman, kata Kebondalem berasal dari kata kebo artinya kerbau dan dalem yang bermakna aku. Sehingga kedua kata ini diartikan sebagai "kerbauku" atau dalam versi lain yakni penghormatan kepada Mbah Kyai Kenduruhan, leluhur yang telah berjasa membangun Desa Kebondalem.

Kebondalem berada di tengah wilayah kecamatan yang berbatasan dengan Desa Bejen (Sebelah Utara), Desa Kemuning (Sebelah Timur), Desa Sidoharjo (Sebelah Selatan) Dan Desa Congkrang (Sebelah Barat). Secara administratif, Desa Kebondalem terbagi menjadi dua Dukuh, dua Rukun Warga (RW) serta 9 Rukun Tetangga (RT). Melalui data desa, tercatat bahwa pada tahun 2018 penduduk Kebondalem berjumlah 1.168 jiwa terbagi atas laki-laki 588 jiwa dan perempuan 580 jiwa dengan jumlah Kepala Keluarga (KK) yaitu 409 jiwa/km2. Mereka mayoritas beragama Islam, Katholik dan Kristen. Desa Kebondalem memiliki berbagai tradisi yakni tradisi Suronan, Nyadran atau Punden, Gojak Blumbang dan Ngideri Desa. Tradisi-tradisi ini masih dilakukan selain untuk menghormati leluhur juga untuk meningkatkan rasa solidaritas antar masyarakat.

Selain nilai tradisi, nilai kebudayaan dan kesenian yang ada di Desa Kebondalem tercermin pula dalam kesenian tradisional Dayakan atau Topeng Ireng yang menjadi kesenian khas daerah ini. Munculnya kesenian Dayakan ini dilatarbelakangi oleh keinginan Bapak Triyanto selaku sesepuh desa yang ingin mengurangi angka kenakalan remaja serta berusaha memberdayakan pemuda-pemudi Kebondalem supaya memiliki kegiatan positif. Kelompok kesenian Dayakan terdiri dari 26 orang yang terbagi dalam penari laki-laki, penari putri dan pengiring musik. Tarian 
ini biasa tampil untuk memperingati hari besar maupun hajat kepentingan warga Kabupaten Temanggung, Kabupaten Wonosobo, dan sekitarnya.

Modernisasi memang telah menggeser fungsi-fungsi awal dari kesenian tradisional, khususnya kesenian Dayakan. Masuknya budaya asing ke Indonesia berbenturan dengan budaya tradisional yang bersifat lokal sehingga fungsi kesenian tradisional mengalami pergeseran. Proses sekularisasi dan komersialisasi yang menghebat pada abad XX memberikan dampak negatif bagi kesenian tradisional. Fungsi ritual, pendidikan serta penggambaran identitas bangsa bergeser menjadi kegiatan komersial yang bersifat hiburan belaka.

Perubahan budaya agraris menjadi budaya semi industrial, peralihan budaya gotong royong ke orientasi profesi, bahkan budaya tolong menolong berganti menjadi budaya formalisme sangatlah berpengaruh pada perubahan visi, persepsi, sikap dan tanggapan masyarakat terhadap kesenian tradisional. Meskipun begitu, kesenian Dayakan berusaha tetap eksis. Hal ini berkat kecintaan pelaku seni dan masyarakat pendukung pada kesenian tersebut. Sehingga untuk lebih meningkatkan kualitas kesenian Dayakan, dibutuhkan adanya kerja pengelolaan yang lebih dikenal dengan istilah "Manajemen Produksi Kesenian Tradisional".

\section{METODE PENELITIAN}

Penelitian ini menggunakan pendekatan deskriptif kualitatif, dengan tujuan menggambarkan dan menjelaskan suatu keadaan sebagaimana adanya. Lokasi penelitian adalah Desa kebondalem tempat Kesenian Dayakan berada. Pengumpulan data penelitian menggunakan metode observasi, wawancara dan studi pustaka. Observasi dilakukan dengan pengamatan langsung dan terencana terhadap kesenian Dayakan untuk memperoleh gambaran yang tepat tentang peran kesenian dalam masyarakat, sejauh mana mereka memfungsikan kesenian tersebut dalam sehari-hari serta bagaimana bentuk pengelolaan kesenian Dayakan yang tepat sebagai upaya revitalisasi seni tradisi. Wawancara yang dilakukan secara langsung kepada para informan yaitu ketua paguyuban dan beberapa masyarakat sebagai penikmat kesenian. Dokumentasi dilakukan dengan cara menelaah bahan dokumen tentang kesenian Dayakan. Dokumen yang diperoleh di lapangan di antaranya adalah artikel dan berita media massa. Adapun 
langkah-langkah analisis merujuk dari Miles dan Huberman (1994), yakni melalui proses reduksi data, sajian data dan penarikan simpulan.

\section{HASIL PENELITIAN}

\section{Sekilas tentang Kesenian Dayakan Kebondalem}

Tarian Dayakan oleh masyarakat luas dikenal dengan nama Topeng Ireng. Kesenian ini rutin dimainkan pada Bulan Agustus dan bulan Sura di lapangan Desa Kebondalem. Masyarakat dalam maupun luar desa serta aparat turut hadir dan terlibat di penyelenggaraan acara tersebut. Selain berkembang di Kebondalem, kesenian Topeng Ireng Dayakan sangat populer di seputar daerah Gunung Merbabu, Merapi, Menoreh serta Sindoro Sumbing. Dayakan adalah bentuk tarian rakyat kreasi baru yang merupakan hasil metamorfosis kesenian Kubro Siswo. Topeng Ireng atau Dayakan hampir mirip dengan Suku Indian di Amerika atau Suku Dayak di Kalimantan. Nama Topeng Ireng sendiri berasal dari kata tata lempeng irama kenceng; tata berarti menata sementara lempeng artinya lurus. Irama memiliki makna nada, dan kenceng berarti keras. Oleh karena itu, kesenian Topeng Ireng Dayakan ini bisa dikatakan sebagai tarian yang para penarinya berbaris lurus dengan iringan musik berirama keras dan penuh semangat. Tarian ini memadukan gerakan syiar agama Islam dengan ilmu bela diri tradisional Jawa atau pencak silat. Kesenian Topeng Ireng mulai berkembang di tengah masyarakat lereng Merapi Merbabu sejak zaman penjajahan Belanda hingga tahun 1960-an. Pada waktu itu, Pemerintahan Belanda melarang masyarakat berlatih silat sehingga mereka mengembangkan berbagai gerakan silat menjadi tarian rakyat. Tarian rakyat berisi nasihat tentang kebaikan hidup dan penyebaran agama Islam dengan musik gamelan dan tembang Jawa sebagai pengiringnya. Gerakan para penari terlihat atraktif, kompak, penuh dengan kedinamisan dan religius.

Kesenian Dayakan di Desa Kebondalem muncul sejak tahun 2012 dan merupakan resapan dari tari Topeng Ireng yang berasal dari Magelang. Kesenian tersebut dipelopori oleh Bapak Triyanto selaku sesepuh dan pemandu kesenian desa. Ia membuat kelompok seni Surya Kawedar yang beranggotakan pemuda pemudi desa kurang lebih 50 orang. Setiap minggu mereka berlatih kesenian Dayakan, baik untuk persiapan tanggapan atau hanya latihan rutin biasa. 
Awalnya di Desa Kebondalem terdapat kesenian Gambus yaitu tarian yang gerakannya menyerupai pencak silat, akan tetapi karena regenerasi yang kurang baik serta sepinya tanggapan pada masa itu meyebabkan kesenian tersebut mati dan sudah tidak berkembang lagi. Oleh karena itu, Bapak Triyanto memiliki inisiatif untuk membangkitkan atau menghidupkan kembali seni tradisi desa dengan menggantikannya dengan kesenian Dayakan. Selain untuk pelestarian budaya, kesenian Dayakan dapat pula menjadi tempat berkegiatan yang positif bagi para remaja Kebondalem. Dengan mendatangkan pelatih dari daerah Tretep, mereka berlatih di balai desa Kebondalem. Jumlah pemain 26 orang, 2 orang pemain perempuan dan 14 orang pemain laki-laki, serta 10 orang pemain musik. Kesenian Dayakan tersebut masih terus berkembang hingga sekarang dan diketuai oleh Bapak Sabar dan Bapak Triyanto. Salah satu hal yang menjadi keistimewaan tarian Dayakan dibandingkan dengan kesenian tradisional lainnya adalah gerakannya yang tidak monoton. Dari waktu ke waktu inovasi baru selalu dilakukan dalam tiap pertunjukan kesenian Dayakan. Pengembangan unsur-unsur artistik dan koreografi dilakukan supaya penontonnya tidak mengalami kebosanan sekaligus untuk menarik minat kaum muda agar mau bergabung menjadi anggota kelompok Dayakan Kebondalem.

Alat musik yang dipakai dalam kesenian Dayakan berperan sebagai pengiring tarian. Gamelan, saron, bonang, suling dan kendang merupakan alat musik yang digunakan sebagai pengiring Dayakan. Sementara kostum merupakan daya tarik utama yang dimiliki oleh kesenian ini. Hiasan bulu warna-warni serupa mahkota kepala suku Indian menghiasi kepala setiap penari. Kostum bagian bawah berupa rok berumbai dengan warna cerah. Untuk alas kaki biasanya mengenakan sepatu gladiator atau sepatu boot dengan gelang kelintingan yang hampir 200 buah setiap pemainnya dan menimbulkan suara riuh gemerincing di tiap gerakannya. Senada dengan mahkota bulunya, riasan wajah para penari dan pakaian para penari juga seperti suku Indian. Riasan pada wajah berbahan dasar seaweed yang di campur dengan minyak goreng dengan berbagai warna yang digunakan yaitu meliputi putih ; artinya bersinar, orange ; berarti cerah (memancarkan auranya), Hitam ; berarti berwibawa atau memberikan efek seram.

Ritual dan sesaji tidak pernah lepas dari kesenian tradisional. Sebelum acara dimulai, juru kunci kesenian Dayakan perlu menyediakan sesajen dengan tujuan agar 
pertunjukan berjalan lancar tanpa kendala apapun. Sesajen itu berupa: kelapa, pisang, kembang arum (mawar, melati, kantil, kenanga, wongso), dupa, kemenyan, kunyit timun, minuman (kopi, teh, dan air putih). Sesajen tersebut dijadikan satu di tampah sebagai penangkal atau untuk menyembuhkan pemain atau orang kesurupan saat pertunjukan kesenian tari Dayakan berlangsung.

Selain alat musik dan kostum, dalam kesenian Dayakan terdapat juga nyanyian yang dibacakan saat tarian berlangsung. Terdapat 13 lagu selama pertunjukan, yaitu meliputi : Aki Sutopo, Atur Sugeng, Pemuda kebondalem, Tresno tanpo welas, Isih tresno, Tombo ati, Stasiun tugu, Cerito wewayangan, Sangu mimpi, Coko boyo, Kelayung-layung, Sawangen, Rupo Kewan. Nyanyian tersebut dinyanyikan kurang lebih 30 menit sampai 45 menit. Biasanya lagu disesuaikan dengan permintaan undangan seperti dalam rangka hajatan meminta tampil dengan durasi waktu 15 menit dengan 5-7 nyanyian saja. Ada beberapa nyanyian yang wajib dilagukan dalam setiap pementasan yaitu nyanyian yang berjudul Pemuda Kebondalem, Rupo Kewan, Aki Sutopo, dan Atur Sugeng. Judul nyanyian lainnya hanya merupakan tambahan saja. Gerakan tari yang dilakukan harus menyesuaikan nyanyian yang dilagukan. Nyanyian inti tersebut digunakan untuk mengiringi gerakan asli dari tarian Dayakan itu sendiri.

\section{Pengelolaan Kesenian Dayakan}

Kesenian Dayakan memiliki bentuk pengelolaan yang masih sederhana dan belum terorganisir dengan baik. Untuk itu diperlukan pengelolaan khusus mengenai manajemen kesenian tradisional supaya kesenian tersebut dapat lebih berkembang dan mampu bersaing dengan kesenian-kesenian lainnya. Sehingga nantinya generasi penerus dapat mengenal dan tetap melestarikan tradisi budaya dan kesenian yang ada di Desa Kebondalem. Beberapa langkah yang dapat dilakukan dalan pengelolaan kesenian tersebut adalah :

\section{Menyusun Struktur Organisasi Produksi}

Kesenian Dayakan Kebondalem meskipun telah memiliki komunitas yaitu kelompok kesenian "Surya Kawedar" namun struktur organisasinya belum tersusun secara maksimal. Padahal struktur organisasi produksi ini diperlukan untuk mempermudah pengelolaan suatu kelompok kesenian. Sehingga perlu dicantumkan seluruh orang-orang yang terlibat bekerja dalam menjalankan produksi tersebut. Hal ini ditindaklanjuti dengan pembentukan struktur organisasi produksi dalam Surya Kawedar 
meskipun dalam bentuk sederhana dengan jumlah orang terbatas. Nantinya diharapkan dapat menjalankan produksi secara efektif dan efisien. Penempatan orang-orang dalam bagian-bagian secara khusus untuk melakukan pekerjaan tertentu dalam produksi. Stuktur organisasinya berupa pimpinan produksi, sekretaris (menyusun proposal dan surat menyurat), bendahara (menyusun anggaran sekaligus mengatur keluar masuknya keuangan), pemasaran (dana, sponsor, publikasi). Selain itu disusun pula tim teknis untuk mengurusi semua masalah logistik (akomodasi, perlengkapan dan peralatan), dan tim artistik untuk mengurusi kostum dan rias. Melalui struktur organisasi yang telah terbentuk diharapkan kesenian Dayakan dapat memproduksi karyanya secara maksimal. 2. Pembenahan Administrasi Organisasi

Administrasi dalam kesenian Dayakan masih bersifat apa danya, hanya berupa catatan-catatan sederhana dan modal percaya antar sesama anggota. Sangat penting dilakukan pembenahan administrasi supaya keaktifan kelompok kesenian tersebut dapat terlihat dan terukur. Selain itu supaya keuangan kelompok dapat dikelola dengan baik dan jelas. Pembenahan administrasi organisasi ini meliputi perbaikan pencatatan buku absensi anggota, pembukuan dan pengarsipan surat masuk dan surat keluar, catatatan pembukuan agenda kegiatan, pembukuan notulen rapat, dan buku keuangan. Pembukuan tersebut dilakukan supaya catatan-catatan yang berkaitan dengan kegiatan organisasi lebih tersusun rapi dan tidak tepisah-pisah sehingga pengelolaan kesenian Dayakan berjalan maksimal dan profesional.

3. Pendaftaran Register di Dinas Kebudayaan dan Pariwisata Kabupaten Temanggung

Pendaftaran register kesenian Dayakan ke Dinas Kebudayaan dan Pariwisata Temanggung telah dilakukan dengan bantuan tim II KKN UNDIP 2018. Pendaftaran tersebut dilakukan dengan berbagai persyaratan yang harus dipenuhi seperti SK dari Kantor Desa, pengorganisasian dan harus adanya administrasi pembukuan. Setelah terregister dan terdaftar di Dinas Pariwisata dan Kebudayan, maka kesenian Dayakan dapat dengan mudah mengembangkan diri memperluas namanya dengan terlibat aktif di berbagai event kesenian yang di luar Kabupaten Temanggung dan mampu bersaing dengan kelompok kesenian lainnya.

Setelah tercatat dalam register, tahapan selanjutnya adalah memproses kelompok kesenian tersebut supaya berbadan hukum. Sesuai informasi yang diperoleh 
dari Dinas Pariwisata dan Kebudayaan Temanggung bahwa status berbadan hukum tersebut akan memudahkan sebuah kelompok kesenian berpeluang untuk bisa mendapatkan bantuan dana atau sponsorship baik dari dalam maupun luar negeri. Untuk mengarah pada kesenian berbadan hukum ada persyaratan yang perlu dilengkapi ssalah satunya adalah adanya AD/ART.

\section{SIMPULAN}

Kesenian Dayakan yang ada di Desa Kebondalem tumbuh dan berkembang sejak tahun 2012 sebagai resapan dari kesenian Topeng Ireng yang ada di Magelang. Pengelolaan kesenian tradisional Dayakan dilakukan dengan beberapa cara meliputi pembentukan struktur organisasi, pembenahan administrasi pembukuan dalam organisasi, pendaftaran register kelompok kesenian dan penyusunan AD/ART untuk proses kesenian yang berbadan hukum. Upaya-upaya ini dilakukan sebagai bentuk revitalisasi kesenian tradisional.

\section{DAFTAR PUSTAKA}

Permas, Achsan, dkk. 2003. Manajemen Organisasi Kesenian Tradisional. Jakarta: PPM.

Martini, Laura Andri. 2007. "Manajemen Kesenian tradisional Ttadisinal di Semarang (Wayang Orang Ngesti Pandowo, Suko Raras dan Sobokarti)".

Sedyawati, Edi. 1981. Pertumbuhan Kesenian Tradisional. Jakarta: Sinar Harapan.

Sutiyono. 2005. "Manajemen Kesenian tradisional Kraton Yogyakarta Sebagai Penanggulangan Krisis Pariwisata Budaya”. (Penelitian UNY Yogyakarta) 